\title{
Research on the Application of the Crime of Falsely Issuing Special VAT Invoices in China
}

\author{
Bozeng Wang ${ }^{1}$ \\ ${ }^{1}$ Beijing Normal University, Beijing, China \\ Correspondence: Bozeng Wang, Beijing Normal University, Beijing, China. E-mail: 18653669189@163.com
}

Received: November 18, 2020

Accepted: December 5, 2020

Online Published: December 14, 2020

doi:10.5539/jpl.v14n2p12

URL: https://doi.org/10.5539/jpl.v14n2p12

\begin{abstract}
Aiming at the low threshold of falsely making out VAT special invoice crime, this paper studies the basis of the crime and the existing problems in the identification, and puts forward some targeted Suggestions: first, to amend the subject of falsely making out VAT special invoice crime; The second is to falsely make out the special VAT invoice as a result of the crime; The third is to strictly master the identification standards of "conceit" behavior; Fourth, the establishment of administrative penalty pre-procedure; Fifth, establish reasonable standard of conviction and sentencing.
\end{abstract}

Keywords: the crime of falsely making out special VAT invoice, problems in identification, suggestions for improvement

\section{Introduction}

Due to the low threshold of criminalization for falsely opening special VAT invoices, such cases have continued to grow in recent years and have become the main type of tax-related crimes. In my opinion, there are some problems in the crime, both in legislation and in the administration of justice, which affect the correct application of the crime. China should raise the threshold of the crime to prevent excessive involvement of criminal means in the field of tax ation.

\section{The Applicable Basis for the Crime of Falsely Opening Special VAT Invoices}

\subsection{Law}

China began in the industrial and commercial manufacturing industry to fully implement the new tax in 1994 . The value-added tax system, while reducing the tax collection and promoting the collection of tax revenue, has also led to an increase in the activities of falsely opening special VAT invoices. In order to combat the act of falsely opening special VAT invoices, the 16th Session of the Standing Committee of the 8th National People's Congress adopted the Decision on Punishing the Crime of Falsely Opening, Falsifying and Illegally Selling Special VAT Invoices on October 30,1995, which criminalizes the act of falsely opening special VAT invoices. The decision states: "Falsely opening a special VAT invoice refers to one of the acts of falsely opening a special VAT invoice for another person, opening it for oneself, letting another person falsely open it for oneself, and introducing another person to falsely opening a special VAT invoice." The decision is a one-line criminal legislation.

China's 1997 Criminal Law incorporates the Contents of the Decision on Punishing the Crime of Falsely Opening, Falsifying and Illegally Selling Special VAT Invoices, and article 205 provides for the crime of falsely opening special VAT invoices. Article 205 of the Criminal Code defines false VAT invoices as basically consistent with the decision of the National People's Congress.

\subsection{Judicial Interpretation}

Since the definition of falsely issuing special VAT invoices in the DECISION of the National People's Congress and the Criminal Law is rather general, the Supreme People's Court issued the "Explanation on the Application of the Decision of the Standing Committee of the National People's Congress on punishing the crime of falsely opening, falsifying and illegally selling Special VAT Invoices " (hereinafter referred to as the "interpretation of the supreme people's court ") in 1996.The interpretation clearly states that "falsely issued special VAT invoices" are the following three acts : (1) Issue VAT invoices for others, for oneself, for oneself or for others or for others without purchasing or selling goods or providing or accepting taxable services; (2) Special VAT invoices with false 
quantity or amount issued for others, for oneself, for others, or for others when goods are purchased or taxable services are provided or accepted; (3) Carry out actual business activities, but let others for their own special VAT invoices.

\subsection{Regulatory Documents of Tax Authorities}

Because the tax work is professional and the power of tax law interpretation is mainly concentrated in the administrative organs, the normative documents of the tax authorities are also an important basis for handling cases of false VAT invoices. Article 3 of Article 1 of the Notice of the State Administration of Taxation on Strengthening the Administration of Value-Added Tax Collection (State Tax Issue No. 1995) stipulates: unit in which the taxpayer purchases goods or taxable services, pays for transportation expenses and pays the amount must be consistent with the unit that issues the deduction certificate and the unit providing the labor service in order to declare the tax deduction, otherwise the deduction shall not be made. Literally, the provision only clarifies the conditions for deducting the amount of income tax and does not consider acts that do not meet the above provisions to be false. However, in practice, this provision is called "third-rate consistent" and becomes an important criterion for determining whether to falsely invoice VAT. "Third-rate" refers to invoice flow, cargo flow, capital flow. "Third rate consistent" refers to the billing unit and the drawee unit consistent, shipping unit and receiving unit consistent, receiving unit and payment unit consistent. Only when "third rate" is consistent at the same time, can it be identified as non-fictitious behavior and tax deduction.

The Announcement of the State Administration of Taxation on issues related to the issue of taxpayers' special VAT invoices to the outside world (State Administration of Taxation Notice No. 39 of 2014) provides guidance for the correct identification of false VAT invoices by providing that they are not part of the act of falsely opening VAT invoices. According to the provisions of the announcement, the issuance of special VAT invoices to foreign countries that conform to the following circumstances shall not be regarded as false issuance of special VAT invoices to foreign countries:(1) the taxpayer sells goods to the drawee taxpayer, or provides VAT taxable services and services; (2) The taxpayer has collected the amount of the goods sold, the taxable services provided or the taxable services provided from the taxpayer of the drawee or has obtained the evidence of soliciting the sales amount; (3) The contents of the VAT special invoice issued by the taxpayer to the drawee in accordance with relevant provisions are consistent with the goods sold, taxable services provided or taxable services provided, and the VAT special invoice is legally obtained by the taxpayer and issued in its own name.

\section{Problems Existing in the Crime of falsely Making out Special VAT Invoices}

\subsection{There Is No Distinction between the Principal and the Accomplice of the Joint Crime}

The role and role of co-offenders in joint crimes are often different, so it is of great significance to distinguish between accomplices and accomplices for correct conviction and sentencing. The correct distinction between the right and the accomplice is directly related to the manifestation of the concept of criminal justice, the maintenance and development of the theory of elements, the nature of the participants in the common crime positioning and the application of punishment. The principal offender is the core and key role of the crime and plays a dominant role in the crime. In principle, he is the person who personally carries out the act conforming to the constitutive requirements. An accomplice has a subordinate position in the crime and does not have a dominant role in the criminal process, and is often the person who commits acts other than the elements, including instigators and aiders The accomplice is a repeat offender, and if the instigator does not commit the instigated crime, the instigator does not commit the crime, and if the aided person does not commit the assisted crime, the helper does not commit the crime.

Among the four acts of falsely opening special VAT invoices stipulated in, it is bound to be a common crime for others to open falsely open for themselves and introduce others. Letting others open for themselves involves letting others open for themselves and false openers, introducing others to falsely opening involving introducers, false openers, and ticketees. China's criminal law will introduce the three main body of the introducer, the false opener, let others for their own false opener side by side, without making a distinction between the right and the accomplice. The author believes that this is not conducive to the correct conviction and sentencing, to combat the crime of false VAT invoices. Such as C a certain introduction to B a false VAT invoice, $\mathrm{C}$ a certain and a false opener A a role in the crime is obviously different, A a certain in the crime play a major role, B a help, promote the role, can only be used as a helper. Again, if A let $\mathrm{b}$ a certain to give themselves a false VAT special invoice, whether the decisionmaking power is falsely opened in B, A a certain criminal intent must be through $\mathrm{B}$ a certain decision and the implementation of false opening behavior can be achieved. B in the knowledge of falsely opening special VAT invoices illegal circumstances, if still issued, obviously in the crime played a major role, B can only be used as an instigator. 


\subsection{The Crime of Falsely Opening Special VAT Invoices Will Be Treated as an Act Offender}

There are four standards for intentional crime stipulated in China's criminal law: resulting crime, behavior crime, dangerous crime, and behavior crime. The result crime takes the occurrence of the legal crime as the mark of the completion and attempted crime. Even if the criminal act has been completed, if the legal harm has not happened, it cannot be regarded as the completion. Behavioral crime refers to the crime that is considered accomplished once the criminal act is completed, no matter whether the harmful result occurs or not. A dangerous crime is one that is deemed accomplished as long as the behavior of the perpetrator causes a dangerous state with some harmful results. According to the degree of danger required by the accomplished crime, it can be divided into abstract dangerous crime and concrete dangerous crime. Act crime refers to the crime which has all the necessary elements to constitute the accomplished crime as long as the actor starts to commit the crime.

In judicial practice, the case handling units generally believe that the perpetrator as long as the implementation of the false special VAT invoice behavior constitutes a crime, regardless of whether the purpose of tax deduction is realized, that is, as a crime. The author believes that this practice reduces the criminalization standard of falsely making out special VAT invoice, expands the scope of application of the crime unduly, and violates the principle of modesty in criminal law.

\subsection{The Criteria for Determining "False Opening” Are Too Broad}

According to the interpretation of the supreme people's court, there are three circumstances under which VAT invoices can be deemed to be falsely issued :(1) issuing VAT invoices for others, for oneself, for others or for others without actual transactions; (2) Special VAT invoices of false quantity or amount issued for others, for oneself, for others or for others in actual transactions; (3) There are actual transactions, but let others for their own special VAT invoices. Because these three standards are not specific and clear enough, the identification standard is too broad in judicial practice, which leads to the problem of expanding the scope of criminalization.

\subsubsection{The "Actual Transaction" Criteria Are Too Strict}

Whether there is an "actual transaction" is an important criterion for judging whether the VAT invoice is falsely issued. In judicial practice, "third-rate consistency" is still an important basis for judgment. At present, business model innovation is constantly emerging. By mixing or splitting some rights and obligations in different business models, new rights and obligations can be created, and then business model innovation can be realized. Innovations in business models may result in transactions that are different in legal form and economic substance. Sticking to the "third-rate consistency" standard would obviously widen the scope of the crime. As follows: One is financial leasing. A financial lease contract is a contract in which the lessor purchases the lease from the lessee and provides it to the lessee for use and the lessee pays the rent according to the lessee's choice of seller and lease. Under the financial lease, the lessor pays the seller, the seller delivers the lease to the lessee, and the flow of funds and goods is obviously inconsistent. If judged according to the "third-rate consistent" standard, improper results can occur. The second is to perform the contract to a third party. If A will sell a batch of goods to B, A, B both sides agreed to pay $\mathrm{C}$ by the direct purchase price of $\mathrm{B}$, in order to pay $\mathrm{A}$ to $\mathrm{C}$ debt. In this case, it will also be suitable for the flow of goods, the flow of funds is inconsistent, but obviously the transaction is legal. Third, creditors exercise the right of se like a substitute. According to Article 73 of the Contract Law, if the debtor causes damage to the creditor by neglecting to exercise its due claim, the creditor may request the people's court to exercise the debtor's claim on its own behalf. Such as A sold to B a batch of goods, but B did not pay as required. A to B debtor C exercise the right of se like, successfully recover the purchase price. In this case, the flow of goods and funds is not consistent.

There are many examples where it is not appropriate to judge the existence of an actual transaction on the basis of the "third-rate consistent" criteria, to name a few.

3.3.2 There Is an Actual Transaction but Let Others Open for Their Own Situation should not Be Recognized as False

The Supreme Law interpretation states that "there is an actual transaction, but let others issue special VAT invoices for themselves" as false. The author believes that this situation should be specifically analyzed, it is not appropriate to be identified as false. If the parties do not evade the purpose of paying taxes, nor actually cause the loss of state taxes, it is not appropriate to be considered false. This is conducive to protecting the interests of entrepreneurs, promoting tax increases and promoting economic development. This is also reflected in the typical case issued by the Supreme People's Court in 2018, in which Zhang yiqiang falsely issued a special VAT invoice.

In 2004, the defendant Zhang Mou strong partnership with others to set up an individual enterprise some keel factory, Zhang Mou strong responsible for production and operation activities. Because some keel factory is small- 
scale taxpayer, cannot issue special invoice of value added tax for buy a unit, Zhang Mou strong then signs sale contract with the name of xinyuan company that other people set up. From 2006 to 2007, Zhang Mou Qiang has signed sales contracts for light steel keel with six companies successively, and the purchasing units will remit the payment to the account of Xinyuan Company. Xinyuan company also issued a total of 53 special VAT invoices for the above six companies, with a total price and tax of RMB 4457,701.36, and tax amount of RMB 647,700.18. Based on the above facts, the people's Procuratorate of a city accused the defendant Zhang Mou strong guilty of falsely making out the special VAT invoice crime. The people's court of a certain state city found the defendant Zhang Mou Qiang guilty of falsely making out special VAT invoices in the first instance, sentenced Zhang Mou Qiang to fixed-term imprisonment of three years, probation of five years, and also fined 50,000 yuan. Zhang did not appeal within the legal time limit, the procuratorate did not protest. But after reviewing, the Supreme People's Court considers that, the defendant zhang strong external sign sales contract, in the name of other units by the unit to charge payment, to issue special VAT invoices, do not have to defraud the purpose of the national tax, thereby causing loss to the national tax, the act does not constitute a crime of falsely making out special invoices for VAT, a strong city people's court ruled that zhang mou constitutes crime of falsely making out special invoices for VAT is applicable law error. Accordingly, the Supreme People's Court ruled that the case be remand for retrial. After the people's court of some state city retries this case, declare Zhang Mou is not guilty lawfully.

\subsubsection{No Pre-Procedure for Administrative Punishment Has Been Set up}

The Amendment to the Criminal Law (VII) changed the crime of tax evasion to the crime of tax evasion, and set up the pre-procedure for administrative punishment: "Those who have been punished for the ACTS mentioned in the first paragraph and have been notified by the tax authorities to make up the amount of tax payable and pay a fine for late payment shall not be investigated for criminal responsibility; However, those who have been subjected to criminal punishment for evading tax payment within five years or have been given administrative punishment more than twice by the tax authorities shall be excluded." The pre-procedure of administrative punishment has limited the criminal law network, reflected the modest and supplementary nature of criminal law, and is of great significance to maintaining the order of tax administration, increasing the state tax revenue, and promoting taxpayers to actively fulfill their tax obligations.

The pre-procedure of administrative punishment embodies the principle of administrative priority and is the opposite of the principle of criminal priority. China has traditionally adhered to the principle of criminal priority, that is, when the same case involves criminal responsibility and administrative responsibility, the judicial organs should give priority to criminal responsibility. As Professor Chen Xingliang pointed out, " The implementation, of the principle of criminal priority is conducive to the fight against crime, and in the case of the competition between administrative punishment and penalty, the implementation of the principle, realization of the social defense capabilities of criminal law. Of course, for individuals who need to be held accountable in a timely manner while pursuing criminal, a public solution with criminal incidental administration may be taken. "

As a tax crime, the crime of falsely making out VAT special invoice has not set up the pre-procedure of administrative punishment, which will inevitably result in the imbalance between the crime of tax evasion and the crime of falsely making out VAT special invoice in terms of criminal punishment. If a party falsely writes a special VAT invoice worth 2.5 million yuan and has not yet deducted the invoice and has not caused any loss of state tax, it will be sentenced to fixed-term imprisonment of not less than 10 years or life imprisonment. However, if a party $\mathrm{B}$ evaded paying tax of 250 yuan, he/she may not be investigated for criminal responsibility after the tax authorities find out and clearly pay the tax and overdue fine and accept the administrative penalty. A party B who has caused a loss of tax revenue of 2.5 million yuan will not be investigated for criminal responsibility, while a party A who has not caused a loss of tax revenue of the state will face a fixed-term imprisonment of more than 10 years or life imprisonment, which obviously leads to the incoordination of criminal punishment and violates the fairness of criminal law. Fan Bingbing, a famous film star who evaded more than 100 million yuan in taxes, has not been prosecuted after paying off taxes, late fees and fines. But she will be prosecuted for falsely issuing a VAT invoice worth 50,000 yuan, which also shows the serious incoordination of criminal punishment.

\subsubsection{The Standard of Guilt Is Unreasonable}

Since the establishment of the crime of falsely issuing special VAT invoices, the amount of conviction and sentencing standard determined by the Law [1996] No. 30 has been applied. Because the amount of conviction and sentencing in this standard is too low, it seriously violates the basic principle of the adaptation of culpability and punishment. Especially compared with the crime of defrauding export tax refunds, the legal benefits and social harm of the two crimes are not much different, but the conviction and sentencing standards are quite different. In order to ensure the crime punishment, on August 22, 2018, the Supreme People's Court issued "about falsely 
making out special invoices for value-added tax conviction sentencing standards related issues notice" ([2018] no. 226), no. 30 [1996] no longer execute method to determine the standard criterions for the conviction, but with reference to the Supreme People's Court on the trial of criminal cases of defrauding export tax rebates "the explanation of the concrete application of the law (no. 30 [2002]). The Notice increases the conviction and sentencing standards for the crime of falsely making out special VAT invoices, raising the conviction standards from 10,000 yuan to 50,000 yuan, the relatively large standards from 100,000 yuan to 500,000 yuan, and the extremely large standards from 500,000 yuan to 2.5 million yuan.

This adjustment embodies the principle of modesty of criminal law, which is conducive to limiting the criminal law network and protecting the legitimate rights and interests of criminal defendants. However, the author believes that after the adjustment of the standard, there are still unreasonable standards for the conviction and sentencing of the crime of falsely opening the special crime of value-added tax. The legal interpretation No. 30 is based on the amount of the actual fraudulent export tax refund, i.e. the amount of the actual tax loss caused by the State. The conviction and sentencing standard for the crime of falsely opening VAT invoices is based on the amount of false invoicing. After falsely opening the special VAT invoice, it is only a danger of illegal tax deduction, under the strict invoice examination system of the tax authorities, whether the deduction can be realized is still unknown. It is obvious that the social harm of falsely opening special VAT invoices (in the case of unrealized deductions) is less than that of fraudulently obtaining export tax rebates (which have actually caused the loss of state tax). In this case, the conviction and sentencing standard for the crime of falsely opening a special VAT invoice is carried out by reference to the conviction and sentencing standard for the crime of fraudulently obtaining export tax rebates, and still can't realize the suitable punishment for the crime.

\section{The Suggestion of Correctly Applying the Crime of Falsely Making out VAT Invoice}

\subsection{Amend the Subject of the Crime of Falsely Opening a Special VAT Invoice}

According to the roles and functions of the co-offender in the joint crime, the subject is divided into principal offender and accomplice, and no one will be regarded as the principal offender or the accomplice for others, the one who makes others open for himself, the one who makes others open for himself, and the one who introduces others. It is suggested that "it is one of the behaviors of opening for others, opening for oneself, letting others open for oneself and introducing others to open for others" be amended to "it is one of the behaviors of opening for others and introducing oneself". The reasons are as follows :(1) it is beneficial to focus on cracking down on the principal criminals who make false invoices, limit the criminal law network, and reflect the supplementary and modest nature of criminal law; (2) Those who allow others to make false statements for themselves (instigators) and those who introduce others to make false statements for themselves (helper crimes) may be dealt with in combination with the provisions of the general provisions of the criminal Law on instigators and helper crimes, and need not be mentioned again in the provisions of the specific provisions; (3) If the accomplice is conducive to the implementation of the principle of complicity, and the false perpetrator does not constitute a crime, the criminal responsibility of the person who makes others open for him (instigator) or introduces others to open for him (helper) should not be investigated separately.

In judicial practice, there have been cases in which the accomplices (those who introduce others and make others open falsely for themselves) are treated differently, and the criminal responsibility is lightly investigated. From May to August 2016, at the request of Zhou, Wang issued 34 copies of value-added tax invoices with a total price and tax of RMB 258,3166.05 and a total tax amount of RMB 375,331.72 for a Certain Trading Company in Beijing, knowing that zhou operated a certain trading company without actual transactions. The above invoices have been fully certified and deducted in the current year, and the relevant taxes have been paid. On June 24, 2019, The Shunyi branch of the Beijing Municipal Public Security Bureau transferred wang xx to the People's Procuratorate of Shunyi District for investigation and prosecution on suspicion of falsely issuing VAT invoices. The People's Procuratorate of Shunyi District, Beijing, decided not to prosecute Wang mou despite the fact that he violated Article 205 of the Criminal Law of the People's Republic of China, but was a first-time offender or an occasional offender, with little subjective malignancy and social danger.

\subsection{The Crime of Falsely Opening Special VAT invoices Is the Result}

Compared with the perpetrators and dangerous offenders, the result of the crime standard is the most stringent, that is, only the result of the actual violation can be investigated for criminal responsibility. The crime of falsely opening a special VAT invoice and falsely opening an invoice for fraudulent export tax refund are stipulated in the same law (Article 205 of the Criminal Law), and the social harm is basically equivalent. However, in judicial practice, the crime of falsely opening special VAT invoices is used as an act, while the crime of falsely opening invoices for fraudulent export tax refund is the result. This means that the crime of falsely opening special VAT 
invoices constitutes a crime as long as there is false opening, and the crime of falsely opening invoices for fraudulent export tax refund constitutes a crime only if the tax is actually fraudulently obtained, resulting in an imbalance in the crime. It is suggested that the crime of falsely opening a special VAT invoice should be treated as a result of the crime, and only when the false VAT invoice actually has a tax credit, it should be treated as a crime. If it does not constitute a crime, administrative penalties may be imposed, such as stopping the sale of invoices to it, disqualifying ordinary taxpayers, and imposing fines.

\subsection{Relax the Criteria for Determining the Act of "False Opening"}

In judicial practice, the judgment of whether there is a "false opening" behavior is often based on the relevant provisions of the tax authorities, such as the "third-rate consistent" relevant provisions. It is suggested that in accordance with the principle of humility, we should strictly grasp the criteria for determining the behavior of "false opening". Use "substance over form" in the judgment of actual transactions

The principle of substantial taxation originated from Germany after the First World War and has been widely applied in various countries (regions) in the world. The core of the principle of substantial taxation is "substance over form", that is, it focuses on the substance of business rather than on the legal provisions. The principle of substantial taxation means that whether a certain situation is taxable cannot be determined only according to its appearance and form, but should be judged according to the actual situation, especially according to its economic purpose and the substance of economic life. In the author's opinion, as long as the following two criteria are met, the existence of an actual transaction can be determined: first, there is a reasonable business purpose; Second, the transaction has practical economic significance to both sides. The principle of substantial taxation concerns the balance between form and substance and aims at the "substantial rationality of law". In the context of Our country, we should limit the power of interpretation by tax authorities, increase the power of interpretation by judicial authorities, and extend the judicial application dimension of the principle of substantial taxation. In judicial practice, judicial authorities should not rely too much on standardized tax documents, abandon "third-rate consistency" and other formal standards, and establish their own feasible judgment standards in accordance with the principle of "substance over form".

\subsection{Set up Pre-Procedures for Administrative Punishment}

Tax crime is an administrative crime, and its criminal illegality is derived from administrative illegality, that is, administrative illegality is the premise of criminal illegality, and it has the dual nature of administrative illegality and criminal illegality. It is suggested that the pre-procedure of administrative penalty should be introduced into the crime of falsely making out special VAT invoices, that is, as long as the criminal suspects pay taxes and late fees in time and accept the administrative penalty, they can be exempted from criminal prosecution. The reasons are as follows: First, it is conducive to strengthening the national tax revenue. The personnel who falsely issue VAT invoices are often the operators of enterprises. Once criminal prosecution procedures are adopted, they will often destroy an enterprise. In the case of joint crimes, they may even destroy several enterprises. The destruction of a business means the destruction of a tax source, which in the long run is bad for the country's tax revenues. The second is to reflect the supplementary nature of criminal law. "Punishment is like a two-edged sword. If it is not properly used, both the state and the individual will suffer from it." If administrative law and other department laws can fully protect benefits, there is no room for criminal law. Criminal law protection is needed only when other department laws are not sufficient to restrain a certain harmful act. "Therefore, the application of penalty should be limited but not expanded, so that penalty becomes the last resort in the protection of interests. When the protection of legal interests can be achieved by other means, the penalty must be waived".

\subsection{Reasonable Standards for Conviction and Sentencing}

Reasonable standard of conviction and sentencing is an important condition for correctly applying the crime of falsely making out special VAT invoice. In order to realize the balance of guilt and punishment, we should change the current pattern of taking the amount of false invoice as the standard of conviction and sentencing, but taking the actual tax loss as the standard. In the author's opinion, referring to the crime of defrauding export tax refund, the conviction and sentencing standards can be stipulated as follows: If the state is defrauded of more than 50,000 yuan of tax due to falsely issuing the special VAT invoice, the amount is "relatively large" as stipulated in Article 204 of the Criminal Law; If the state is defrauded of more than 500,000 yuan of tax due to falsely issuing a special VAT invoice, the amount shall be "enormous" as stipulated in Article 204 of the Criminal Law; If the state is defrauded of more than 2.5 million yuan of tax due to falsely issuing a special VAT invoice, the amount shall be "extremely huge" as stipulated in Article 204 of the Criminal Law.

Because of the simple act of falsely opening THED invoice, it also has the danger of causing the state tax to be defrauded, and it is necessary to regulate the use of criminal law to reach the larger amount standard. It is proposed 
that, after the revision of the standard of conviction and sentencing, the attempted act of falsely opening a special VAT invoice (not realizing the deduction) be dealt with as an attempt to falsely issue a special VAT invoice, i.e., in accordance with article 23, paragraph 2 , of the Criminal Code, the penalty shall be reduced or reduced in accordance with the previous offence.

In a word, raising the threshold of the crime of falsely opening special VAT invoices is of great significance for protecting the legitimate rights and interests of taxpayers and increasing the national fiscal revenue.

\section{References}

Gao, M. X., \& Mark, C. (2016). Criminal Law. Beijing: Peking University Press.

Huang, T. Y. (2009). Interpretation of Criminal Law Amendment (VII). People's Procuratorial Work, (6).

Lu, O. C., \& Zhang, J. H. (2018). Path Reshaping of the principle of substantial Taxation, (1).

Sun, G. L. (2017). Research on dependence and Independence of administrative Illegality Judgment. Jurists, (1).

Tang, J. Y. (2010). Tax Regulation of Financial Innovation. Beijing: Law Press.

Zhang, M. K. (2007). Criminal Law. Beijing: Law Press.

Zhu, C. S. (2016). Also on "Third-rate consistency" and "False opening". Finance and Accounting, (21).

\section{Copyrights}

Copyright for this article is retained by the author(s), with first publication rights granted to the journal.

This is an open-access article distributed under the terms and conditions of the Creative Commons Attribution license (http://creativecommons.org/licenses/by/4.0/). 